\title{
FAKTOR PENYEBAB KEJADIAN INFEKSI SALURAN PERNAFASAN AKUT (ISPA) DI MUSIM KEMARAU PADA MASYARAKAT WILAYAH KERJA PUSKESMAS KAMPAR
}

\author{
Wahyuni Usman $^{1}$, John Taruna ${ }^{2}$, Nila Kusumawati ${ }^{3}$ \\ S1 Kesehatan Masyarakat Universitas Pahlawan Tuanku Tambusai \\ wahyuniusman19@gmail.com ${ }^{1}$, nilakusumawati@univpahlawan.ac.id ${ }^{2}$
}

\begin{abstract}
ARI (Acute Respiratory Infection) is an acute inflammation of upper and lower respiratory tract. ARI is caused by a virus / bacteria that begins with heat accompanied by one or more symptoms such as sore throat, swallowing pain, runny nose, dry cough or phlegm. ARI is a public health problem in developing countries. The incidence of ARI tends to increase during the dry season.The goal of this research is want to know factors causing the event of ARI in dry season at public health center of kampar 2020. This research is observational analytic study with case control study design. Based on the results of research in the Kampar Public health center. The population is suffering from this research is the people in the Kampar Public health center and the samples is the people whos cames to Public health center to get treatment. Sample of case is 52 people and sample of control is 52 people. The variable in this research is Personal Protective equipments. The data were analyzed by univariate and bivariate analysis using Pearson correlation test and simple linier regression.The result of this research is that there is a significant correlation of using personal protective equipments with ARI in the dry season with ( $p$ value $<0,01)$. The preventive of action that can be done by the community is that if driving in the dry season, you should use PPE (Personal Protective equipments) like a mask, and if you are often active in the sun, you should use protective clothing such as hats, long sleeves, trousers and hats to avoid direct sun exposure.
\end{abstract}

Keywords : ARI in the dry season, PPE

\section{ABSTRAK}

Infeksi Saluran Pernafasan Akut (ISPA) adalah radang akut saluran pernafasan atas maupun bawah. ISPA disebabkan oleh virus/bakteri yang diawali dengan panas dengan disertai salah satu atau lebih gejala seperti tenggorokan sakit, nyeri telan, pilek, batuk kering atau berdahak. ISPA merupakan masalah kesehatan masyarakat dinegara berkembang. Angka kejadian ISPA cenderung mengalami peningkatan pada musim kemarau. Penelitian ini bertujuan untuk mengetahui faktor-faktor penyebab kejadian ISPA di musim kemarau pada masyarakat wilayah kerja Puskeskmas Kampar tahun 2020. Jenis penelitian ini adalah observasional analitik dengan desain penelitian Case control yaitu suatu penelitian survey analitik yang menyangkut bagaimana faktor resiko dipelajari dengan pendekatan retrospektif. Populasi dalam penelitian ini adalah masyarakat di wilayah kerja Puskesmas Kampar, dengan sampelnya yaitu masyarakat wilayah kerja Puskesmas Kampar yang datang berkunjung ke puskesmas untuk berobat dengan jumlah sampel kasus sebanyak 52 responden dan sampel kontrol sebanyak 52 responden. Variabel dalam penelitian ini adalah penggunaan alat pelindung diri. Analisis data yang digunakan mencakup analisis univariat dan bivariat menggunakan uji chi-square. Hasil penelitian dengan uji statistik menunjukkan ada hubungan yang signifikan antara faktor penggunaan alat pelindung diri dengan kejadian ISPA di musim kemarau yaitu dengan ( $p$ value $<0,01)$. Tindakan pencegahan yang dapat dilakukan oleh masyarakat adalah jika berkendara pada musim kemarau sebaiknya menggunakan APD seperti masker, dan jika sering beraktivitas dibawah terik matahari sebaiknya menggunakan pakaian pelindung seperti topi, beju lengan panjang, celana panjang serta topi agar terhindar dari paparan matahari secara langsung.

Kata Kunci : ISPA di Musim Kemarau, APD. 


\section{PENDAHULUAN}

Infeksi Saluran Pernafasan Akut (ISPA) adalah penyakit infeksi akut yang menyerang salah satu bagian/lebih dari saluran nafas mulai hidung alveoli termasuk adneksanya (sinus rongga telinga tengah pleura) (Depkes, 2013). Berdasarkan laporan Riset Kesehatan Dasar (Riskesdas) tahun 2013 ISPA disebabkan oleh virus/bakteri yang diawali dengan panas dengan disertai salah satu atau lebih gejala (tenggorokan sakit, nyeri telan, pilek, batuk kering atau berdahak) (Kemenkes RI, 2013) .

Menurut World Health Organization (WHO) tahun 2016 jumlah penderita ISPA adalah 59.417 kasus dan memperkirakan di negara berkembang berkisar 40-80 kali lebih tinggi dari negara maju. Infeksi Saluran Pernapasan Akut merupakan penyebab kematian dan kesakitan di Indonesia. Untuk meningkatkan upaya perbaikan kesehatan masyarakat, Departemen Kesehatan RI menetapkan 10 program prioritas masalah kesehatan yang ditemukan di masyarakat untuk mencapai tujuan Indonesia Sehat, dimana salah satu diantaranya adalah Program Pencapaian Penyakit Menular termasuk penyakit ISPA (Depkes RI, 2012).

Tingginya kasus ISPA cenderung dipengaruhi oleh beberapa faktor risiko antara lain kondisi ekonomi, kependudukan, perilaku hidup bersih dan sehat (PHBS) dan perubahan iklim global seperti musim kemarau. Pada musim kemarau jalanan akan lebih banyak berdebu, debu tersebut akan beterbangan masuk ke dalam rumah dan menempel di perabotan rumah tangga seperti : meja, kursi, jendela ataupun lantai sehingga debu tersebut dengan mudah terhirup oleh manusia secara terus- menerus yang dapat menggangu sistem pernafasan manusia dan dapat menyebabkan ISPA (Lakin Dinkes Riau, 2018).

Cuaca yang panas dan radiasi matahari yang langsung terpapar ke pekerja dapat mempengaruhi kesehatan tubuh pekerja seperti penyakit flu, pusing, dehidrasi, demam, mempersempit saluran pernafasan dan dapat juga menyebabkan melemahnya sistem imun. Sistem imun seseorang sangat berpengaruh dalam melawan infeksi virus maupun bakteri terhadap tubuh manusia. Kondisi seperti ini membuat seseorang semakin mudah terserang oleh ISPA (Rismawati dkk, 2016).

Banyaknya debu, asap dan panasnya cahaya matahari pada musim kemarau mengharuskan seseorang untuk menggunakan Alat Pelindung Diri (APD) seperti masker yang merupakan faktor pencegahan agar terhindari dari penyakit ISPA. Menurut penelitian yang dilakukan oleh Ahmad (2017), didapatkan hasil bahwa ada hubungan yang bermakna antara penggunaan masker pada pekerja lapangan dengan frekuensi kejadian ISPA. Pemakaian APD seperti masker debu jenis N95 merupakan salah satu upaya yang dapat dilakukan untuk mengurangi gangguan kesehatan paru akibat polusi udara luar ruangan terkait kebakaran hutan (Haruyuki, 2017).

APD yang digunakan pada saat seseorang bekerja di luar ruangan dan langsung terpapar oleh panas adalah topi, baju lengan panjang dan celana panjang agar terhindar dari paparan panas secara langsung. Paparan cahaya matahari secara langsung dapat menimbulkan daya tahan tubuh yang menurun sehingga tubuh akan rentan terserang flu dan berbagai gejala penyakit infeksi seperti ISPA. Hal ini sejalan dengan penelitian yang dilakukan oleh Ida (2016) yang menyebutkan bahwa penggunaan APD seperti topi, baju lengan panjang dan celana panjang pada pekerja diluar lapangan sangatlah penting agar terhindar dari panasnya cahaya matahari yang dapat menurunkan daya tahan tubuh sehingga rentan menyebabkan ISPA.

Dari hasil survei pendahuluan yang dilakukan kepada 10 orang pengunjung Puskesmas Kampar pada bulan April 2020, didapatkan hasil sebanyak 6 orang 
pengunjung mengalami ISPA pada musim kemarau sedangkan 4 orang lainnya mengalami ISPA pada saat bukan musim kemarau. Mereka mengalami ISPA disebabkan oleh banyaknya paparan asap dan debu pada saat musim kemarau serta mereka tidak menggunakan APD seperti masker saat keluar rumah.

Berdasarkan informasi di atas, dapat diketahui bahwa hingga saat ini sudah banyak penelitian yang dilakukan untuk mengetahui faktor penyebab ISPA saat musim hujan, akan tetapi masih belum banyak informasi yang menjelaskan tentang faktor-faktor penyebab ISPA di musim kemarau, musim yang terjadi jauh lebih lama dibandingkan dengan musim hujan di negara-negara tropis seperti Indonesia. Melalui penelitian ini peneliti tertarik untuk meneliti "Faktor-faktor Penyebab Kejadian ISPA di Musim Kemarau Tahun 2020". Adapun faktorfaktor yang akan diteliti adalah penggunaan APD. Subjek dalam penelitian ini adalah masyarakat yang berada di wilayah kerja Puskesmas Kampar, Kecamatan Kampar, Kabupaten Kampar.

\section{METODE}

Jenis penelitian ini adalah observasional analitik dengan desain penelitian Case control yaitu suatu penelitian survey analitik yang menyangkut bagaimana faktor resiko dipelajari dengan pendekatan retrospektif. Penelitian ini di lakukan di wilayah kerja Puskesmas Kampar yang dilakukan pada awal musim kemarau pada tanggal 10 Juni s/d 2 Juli tahun 2020. Populasi dalam penelitian ini adalah masyarakat di wilayah kerja Puskesmas Kampar, dengan sampelnya yaitu masyarakat yang datang berkunjung ke puskesmas untuk berobat dengan jumlah sampel kasus sebanyak 52 responden dan sampel kontrol sebanyak 52 responden.

\section{HASIL}

Analisis Univariat

Tabel 4.1 Distribusi Frekuensi Responden Berdasarkan Variabel Asap, Debu, Panas dan Cahaya Matahari, dan Alat Pelindung Diri di Wilayah Kerja Puskesmas Kampar Tahun 2020.

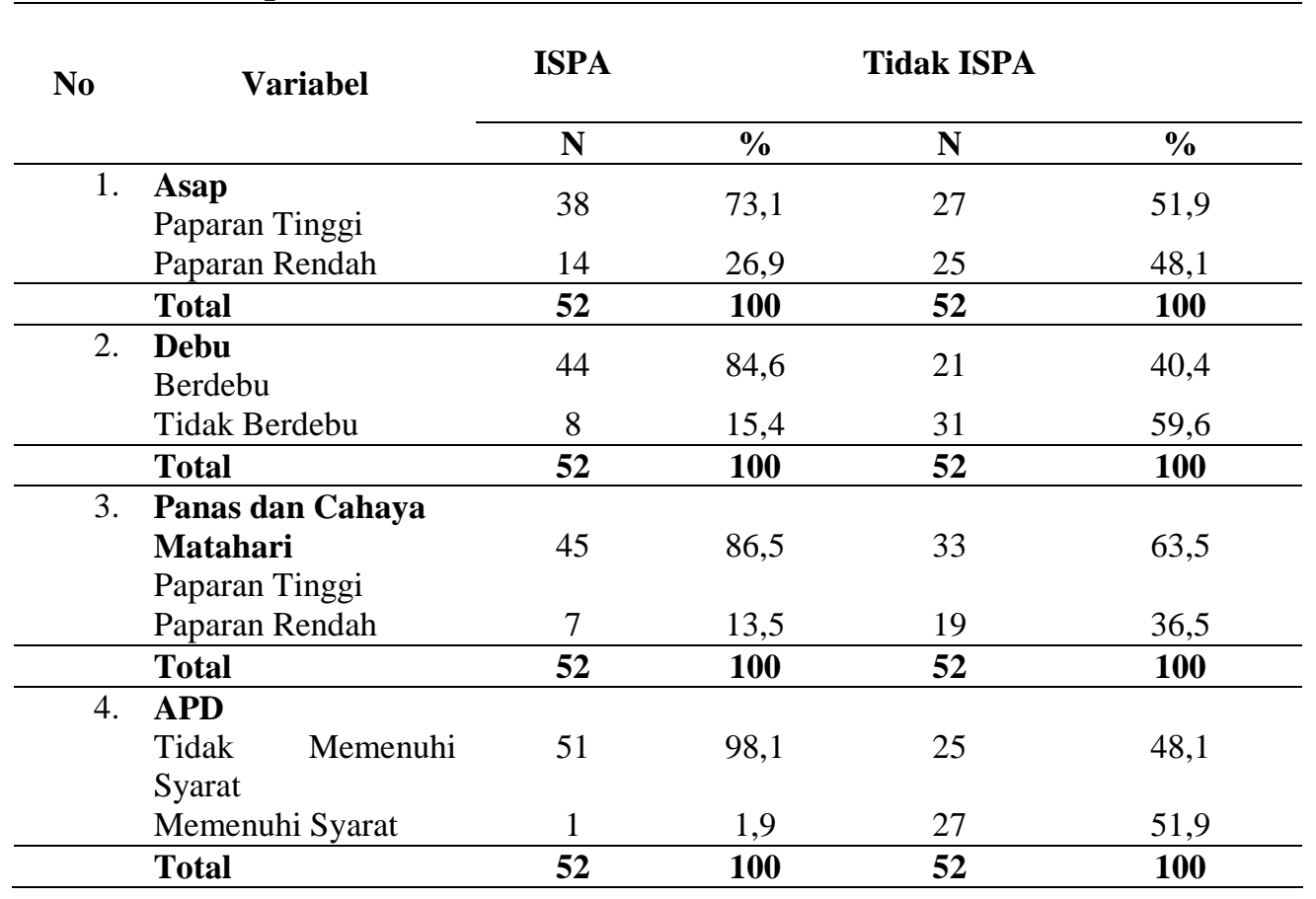


Dari Tabel 4.1 dapat diketahui bahwa dari 52 responden dengan kategori ISPA, terdapat 38 orang $(73,1 \%)$ paparan tinggi terhadap asap, 44 orang $(84,6 \%)$ berdebu, 45 orang $(86,5 \%)$ paparan tinggi terhadap panas dan cahaya matahari, 51 orang $(98,1 \%)$ tidak memenuhi syarat dalam penggunaan
APD. Sedangkan dari 52 responden dengan kategori tidak ISPA, terdapat 27 orang $(51,9 \%)$ paparan tinggi terhadap asap, 21 orang $(40,4 \%)$ berdebu, 33 orang $(63,5 \%)$ paparan tinggi terhadap panas dan cahaya matahari, dan 25 orang $(48,1 \%)$ tidak memenuhi syarat dalam penggunaan APD.

\section{Analisis Bivariat}

Faktor Asap

Hasil uji statistik dengan menggunakan chi square untuk faktor asap dapat dilihat sebagai berikut :

Tabel 4.3 Distribusi Kejadian ISPA Menurut Paparan Asap di Musim Kemarau pada Wilayah Kerja Puskesmas Kampar Tahun 2020.

\begin{tabular}{|c|c|c|c|c|c|c|c|c|}
\hline \multirow{3}{*}{ Asap } & \multicolumn{4}{|c|}{ Kejadian ISPA } & & & \multirow[b]{2}{*}{ OR (CI 95\%) } & \multirow[b]{2}{*}{$p$ value } \\
\hline & \multicolumn{2}{|c|}{ ISPA } & \multicolumn{2}{|c|}{ Tidak ISPA } & \multicolumn{2}{|c|}{ Total } & & \\
\hline & $\mathbf{n}$ & $\%$ & $\mathbf{n}$ & $\%$ & $\mathbf{N}$ & $\%$ & & \\
\hline $\begin{array}{l}\text { Paparan } \\
\text { Tingggi }\end{array}$ & 38 & 73,1 & 27 & 51,9 & 65 & 62,5 & $251(111=70)$ & $\mathbf{0 , 0 4}$ \\
\hline $\begin{array}{l}\text { Paparan } \\
\text { Rendah }\end{array}$ & 14 & 26,9 & 25 & 48,1 & 39 & 37,5 & $2, \mathrm{~J} 1(1,11-5, / 0)$ & \\
\hline Total & 52 & 100 & 52 & 100 & 104 & 100 & & \\
\hline
\end{tabular}

Berdasarkan Tabel 4.3 diketahui bahwa dari 52 responden dengan kategori ISPA, terdapat 38 responden $(73,1 \%)$ dengan kategori paparan tinggi. Sedangkan dari 52 responden dengan kategori tidak ISPA, terdapat 27 responden $(51,9 \%)$ dengan ketegori paparan tinggi.

Hasil uji statistik didapatkan nilai chi square $4,10(>3,841)$ dan nilai $p$ value
$=0,04$ berarti terdapat hubungan yang signifikan antara paparan tinggi asap dengan kejadian ISPA di musim kemarau pada wilayah kerja Puskesmas Kampar tahun 2020. Didapat nilai OR 2,51 (95\% CI :1,021-2,597) artinya pada kelompok kasus ISPA terkena faktor risiko asap 2,51 kali lebih besar dari pada kelompok tidak ISPA

\section{Faktor Debu} berikut :

Hasil uji statistik dengan menggunakan chi square untuk faktor debu dapat dilihat sebagai

Tabel 4.4 Distribusi Kejadian ISPA Menurut Paparan Debu di Musim Kemarau pada Wilayah Kerja Puskesmas Kampar Tahun 2020.

\begin{tabular}{|c|c|c|c|c|c|c|c|c|}
\hline \multirow{3}{*}{ Debu } & \multicolumn{4}{|c|}{ Kejadian ISPA } & & & \multirow{3}{*}{ OR (CI 95\%) } & \multirow[b]{2}{*}{$p$ value } \\
\hline & \multicolumn{2}{|c|}{ ISPA } & \multicolumn{2}{|c|}{ Tidak ISPA } & \multicolumn{2}{|c|}{ Total } & & \\
\hline & $\mathbf{n}$ & $\%$ & $\mathbf{n}$ & $\%$ & n & $\%$ & & \\
\hline Berdebu & 44 & 84,6 & 21 & 40,4 & 65 & 62,5 & & $<001$ \\
\hline $\begin{array}{l}\text { Tidak } \\
\text { Berdebu }\end{array}$ & 8 & 15,4 & 31 & 59,6 & 39 & 37,5 & $8,12(3,19-20,68)$ & $\langle 0,0\rangle$ \\
\hline Total & 52 & 100 & 52 & 100 & 104 & 100 & & \\
\hline
\end{tabular}


Berdasarkan Tabel 4.4 dapat diketahui bahwa dari 52 responden dengan kategori ISPA, terdapat 44 responden $(84,6 \%)$ dengan kategori berdebu, sedangkan dari 52 responden dengan kategori tidak ISPA, terdapat 21 responden $(40,4 \%)$ dengan ketegori berdebu.

Hasil uji statistik didapatkan nilai chi square 19,86 dan nilai $p$ value $<0,01$ berarti terdapat hubungan yang sangat signifikan antara berdebu dengan kejadian ISPA di musim kemarau pada wilayah kerja Puskesmas Kampar tahun 2020. Didapat nilai OR 8,12 (95\% CI : 3,19-20,68) artinya pada kelompok kasus ISPA terkena faktor risiko debu 8,12 kali lebih besar dari pada kelompok tidak ISPA.

\section{Faktor Panas dan Cahaya Matahari}

Hasil uji statistik dengan menggunakan chi square untuk faktor panas dan cahaya matahari dapat dilihat sebagai berikut :

Tabel 4.5 Distribusi Kejadian ISPA Menurut Paparan Panas dan Cahaya Matahari di Musim Kemarau pada Wilayah Kerja Puskesmas Kampar Tahun 2020.

\begin{tabular}{|c|c|c|c|c|c|c|c|c|}
\hline \multirow{3}{*}{$\begin{array}{c}\text { Panas dan } \\
\text { Cahaya } \\
\text { Matahari }\end{array}$} & \multicolumn{4}{|c|}{ Kejadian ISPA } & & & \multirow{3}{*}{ OR (CI 95\%) } & \multirow{3}{*}{ p value } \\
\hline & \multicolumn{2}{|c|}{ ISPA } & \multicolumn{2}{|c|}{ Tidak ISPA } & \multicolumn{2}{|c|}{ Total } & & \\
\hline & $\mathbf{n}$ & $\%$ & $\mathbf{n}$ & $\%$ & $\mathbf{n}$ & $\%$ & & \\
\hline $\begin{array}{l}\text { Paparan } \\
\text { Tinggi }\end{array}$ & 45 & 86,5 & 33 & 63,5 & 78 & 75 & $3.70(1.40-9.82)$ & $\mathbf{0 , 0 1}$ \\
\hline $\begin{array}{l}\text { Paparan } \\
\text { Rendah }\end{array}$ & 7 & 13,5 & 19 & 36,5 & 26 & 25 & & \\
\hline Total & 52 & 100 & 52 & 100 & 104 & 100 & & \\
\hline
\end{tabular}

Berdasarkan Tabel 4.5 diketahui bahwa dari 52 responden dengan kategori ISPA, terdapat 45 responden $(86,5 \%)$ dengan kategori paparan tinggi. Sedangkan dari 52 responden dengan kategori tidak ISPA, terdapat 33 responden $(63,5 \%)$ dengan ketegori paparan tinggi.
Hasil uji statistik didapatkan nilai chi square 6,21 dan nilai $P$ value $=0,01$ berarti terdapat pengaruh yang signifikan antara paparan tinggi panas dan cahaya matahari di musim kemarau dengan kejadian ISPA pada wilayah kerja Puskesmas Kampar tahun 2020.

\section{Faktor Alat Pelindung Diri}

Hasil uji statistik dengan menggunakan chi square untuk faktor alat pelindung diri dapat dilihat sebagai berikut :

Tabel 4.6 Distribusi Kejadian ISPA Menurut Alat Pelindung Diri di Musim Kemarau pada Wilayah Kerja Puskesmas Kampar Tahun 2020.

\begin{tabular}{|c|c|c|c|c|c|c|c|c|}
\hline \multirow{3}{*}{ APD } & \multicolumn{4}{|c|}{ Kejadian ISPA } & & & \multirow{3}{*}{ OR (CI 95\%) } & \multirow{3}{*}{ p value } \\
\hline & \multicolumn{2}{|c|}{ ISPA } & \multicolumn{2}{|c|}{ Tidak ISPA } & \multicolumn{2}{|c|}{ Total } & & \\
\hline & $\mathbf{n}$ & $\%$ & $\mathbf{n}$ & $\%$ & $\mathbf{n}$ & $\%$ & & \\
\hline $\begin{array}{l}\text { Tidak } \\
\text { Memenuhi } \\
\text { Syarat }\end{array}$ & 51 & 98,1 & 25 & 48,1 & 76 & 73,1 & $55,08(7,07-428,92)$ & $<0,01$ \\
\hline $\begin{array}{l}\text { Memenuhi } \\
\text { Syarat }\end{array}$ & 1 & 1,9 & 27 & 51,9 & 28 & 26,9 & & \\
\hline Total & 52 & 100 & 52 & 100 & 104 & 100 & & \\
\hline
\end{tabular}


Berdasarkan Tabel 4.6 dapat diketahui bahwa dari 52 responden dengan kategori ISPA, terdapat 51 responden $(98,1 \%)$ dengan kategori tidak memenuhi syarat dalam penggunaan APD. Sedangkan dari 52 responden dengan kategori tidak ISPA, terdapat 25 responden $(48,1 \%)$ dengan ketegori tidak memenuhi syarat dalam penggunaan APD.

Hasil uji statistik didapatkan nilai chi square 30,55 dan nilai $P$ value $<0,01$ berarti terdapat hubungan yang sangat signifikan antara tidak memenuhi syarat dalam penggunaan APD dengan kejadian ISPA di musim kemarau pada wilayah kerja Puskesmas Kampar tahun 2020. Didapat nilai OR 55,08 (95\% CI: 7,07428,92) artinya pada kelompok kasus ISPA terkena faktor APD 55,08 kali lebih besar dari pada kelompok tidak ISPA.

\section{PEMBAHASAN}

Hubungan Faktor APD dengan Kejadian ISPA di Musim Kemarau Pada Masyarakat Wilayah Kerja Puskesmas Kampar

Hasil penelitian dari 52 responden dengan kategori ISPA, terdapat 51 responden $(98,1 \%)$ dengan kategori tidak memenuhi syarat dalam penggunaan APD. Sedangkan dari 52 responden dengan kategori tidak ISPA, terdapat 25 responden $(48,1 \%)$ dengan ketegori tidak memenuhi syarat dalam penggunaan APD.

Hasil uji statistik didapatkan nilai $p$ value $<0,01$ berarti terdapat hubungan yang sangat signifikan antara tidak memenuhi syarat dalam penggunaan APD dengan kejadian ISPA di musim kemarau pada wilayah kerja Puskesmas Kampar Tahun 2020. Didapat nilai OR 55,08 (95\% CI: 7,07-428,92) artinya pada kelompok kasus ISPA terkena factor penggunaan APD 55,08 kali lebih besar dari pada kelompok tidak ISPA, maka artinya faktor APD berhubungan sangat signifikan dengan kejadian ISPA di musim kemarau.

Hasil penelitian ini sejalan dengan penelitian yang dilakukan oleh Ahmad
(2017) dengan judul "Hubungan penggunaan masker pada tukang ojek dengan kejadian ISPA" dengan hasil penelitian menunjukkan bahwa terdapat hubungan penggunaan masker dengan ISPA $(p=0,030)$. Banyaknya debu, asap dan panasnya cahaya matahari pada musim kemarau mengharuskan seseorang untuk menggunakan Alat Pelindung Diri (APD) seperti masker yang merupakan faktor pencegahan agar terhindari dari penyakit ISPA.

APD yang digunakan pada saat seseorang bekerja di luar ruangan dan langsung terpapar oleh panas adalah topi, baju lengan panjang dan celana panjang agar terhindar dari paparan panas secara langsung. Paparan cahaya matahari secara langsung dapat menimbulkan daya tahan tubuh yang menurun sehingga tubuh akan rentan terserang flu dan berbagai gejala penyakit infeksi seperti ISPA. Hal ini sejalan dengan penelitian yang dilakukan oleh Ida (2016) yang menyebutkan bahwa penggunaan APD seperti topi, baju lengan panjang dan celana panjang pada pekerja diluar lapangan sangatlah penting agar terhindar dari panasnya cahaya matahari yang dapat menurunkan daya tahan tubuh sehingga rentan menyebabkan ISPA.

Menurut peneliti pada responden yang memenuhi syarat dalam penggunaan APD tetapi mengalami ISPA, berarti responden tersebut mengalami ISPA bukan karena faktor penggunaan APD, tetapi karena faktor internal dari responden seperti status gizi dan riwayat penyakit. Hal ini sesuai dengan penelitian yang dilakukan oleh diana (2016) yang menyebutkan bahwa status gizi dan riwayat penyakit merupakan salah satu faktor yang dapat menyebabkan ISPA. Karena jika status gizi rendah maka akan sangat mudah untuk menderita ISPA yang disebabkan oleh microorganisme hal ini terjadi diakibatkan oleh tidak kuatnya kekebalan tubuh dari seseorang untuk melawan kuman dan bakteri yang dapat menyebabkan penyakit. 


\section{KESIMPULAN}

Dari hasil penelitian dan pembahasan pada bab-bab sebelumnya tentang "Faktor-faktor penyebab kejadian ISPA di musim kemarau pada masyarakat wilayah kerja puskesmas kampar" dapat disimpulkan bahwa proporsi kasus ISPA yang disebabkan oleh tingginya paparan asap sebanyak 38 orang $(73,1 \%)$, yang disebabkan oleh debu sebanyak 44 orang $(84,6 \%)$, disebabkan oleh tingginya paparan panas dan cahaya matahari sebanyak 45 orang $(86,5 \%)$, disebabkan oleh penggunaan APD yang tidak memenuhi syarat sebanyak 51 orang $(98,1 \%)$, dan sedangkan yang disebabkan oleh ventilasi yang tidak memenuhi syarat kasus ISPA sebanyak 46 orang $(88,5 \%)$. Proporsi kasus tidak ISPA yang mengalami paparan yang tinggi tetapi tidak mengalami ISPA yaitu sebanyak 27 orang $(51,9 \%)$, yang terpapar debu tetapi tidak ISPA sebanyak 21 orang $(40,4 \%)$, yang mengalami tinggi paparan panas dan cahaya matahari tetapi tidak mengalami ISPA sebanyak 33 orang $(63,5 \%)$, yang tidak memenuhi syarat dalam penggunaan APD tetapi tidak ISPA sebanyak 25 orang $(48,1 \%)$, dan sedangkan ventilasi yang tidak memenuhi syarat tetapi tidak mengalami ISPA sebanyak 15 orang $(28,8 \%)$.

\section{DAFTAR PUSTAKA}

Alsagaff H, dan Mukty H.A. 2010. Dasardasar Ilmu Penyakit Paru. Surabaya: Airlangga University Press.

Ayu Risma, Ifa.2019. Faktor - Faktor Yang Berhubungan Dengan Kejadian ISPA Pada Pekerja Home Industry Batu Bata Di Desa Klenco. [skripsi]. Madiun: Agustus 2019.

Basti, Alya Mutiara, 2014. Kadar Debu Total Dan Gejala ISPA Ringan Pada Pekerja Pemintalan Di
Industri Tekstil PT. Unitex, Tbk Bogor.

Budiono, Sugeng A.M, 2003. Bunga Rampai Hiperkes \& Keselamatan Kerja, Semarang Universitas Negeri Diponegoro.

Chandra, Budiman. 2007. Pengantar Kesehatan Lingkungan. Penerbit : Buku Kedokteran EGC. Jakarta.

Departemen Kesehatan Republik Indonesia. 2009. Profil Kesehatan Indonesia 2008. Jakarta : Depkes RI.P. 39-40.

Dinas Kesehatan Provinsi Riau.2019. Profil Kesehatan Provinsi Riau Tahun 2018. Riau : Dinas Kesehatan Provinsi Riau.

Dinas Kesehatan Provinsi Riau. 2019. Laporan Kinerja Intansi Pemerintah Tahun 2018 . Riau : Dinas Kesehatan Provinsi Riau.

Dinas Kesehatan Kabupaten Kampar. 2019. Profil Kesehatan Kabupaten Kampar Tahun 2018. Bangkinang : Dinas Kesehatan Kabupaten Kampar.

Departemen Kesehatan RI. 2018. Direktorat Jenderal Pemberantasan Penyakit Menular dan Penyehatan Lingkungan (P2M dan PL) . Jakarta: Depkes RI.

Elma putri, Anindea. 2017. Faktor-Faktor Yang Berhubungan Dengan Kejadian Ispa Pada Orang Dewasa Di Desa Besuk Kecamatan Bantaran Kabupaten Probolinggo. Jurnal Ilmiah Kesehatan Media Husada. Vol. 6, No.1. Maret 2017 $: 1-9$.

Marianta, Desi. 2016. Hubungan Kualitas Fisik Rumah Terhadap Kejadian Ispa Pasca Bencana Erupsi Gunung Sinabung Di Wilayah 
Kerja Puskesmas Kecamatan Tiganderket Karo Sumatera Utara Pada Tahun 2015. [Skripsi]. Medan : Universitas Sumatera Utara.

Notoatmodjo, S. 2002. Metodologi Penelitian Kesehatan.Edisi Revisi. Rineka Cipta: Jakarta.

\begin{tabular}{lll} 
& 2007. & Promosi \\
\hline kesehatan & dan ilmu & perilaku. \\
Rineka cipta : Jakarta. &
\end{tabular}
2010. Metodologi Penelitian Kesehatan. Jakarta : Rineka Cipta.

\section{Metodologi Penelitian Kesehatan. Jakarta: Rineka Cipta.}

Pudul, Selfiana. 2015. Hubungan konsentrasi debu dan kelembaban udara terhadap kejadian infeksi saluran pernapasan akut (ispa) di kecamatan mapanget kota manado. Jurusan Kesehatan Lingkungan Poltekkes Manado. Hal 1-10.

Purnaini, Riki. 2011. Perencanaan Pengelolaan Sampah di Kawasan Selatan Universitas Tanjung pura. Jurnal Teknik Sipil UNTANVol. 11 No. 1, Hal. 2-3.

Prasetya, BY, 2005. Mendesain Rumah Tropis. PT. Trubus Agriwidya, Semarang.

Ratnani, R.D. 2008. Teknik Pengendalian Pencemaran Udara yang Diakibatkan oleh
Partikel.Semarang: Jurusan Teknik Kimia Universitas Wahid Hasyim.

Rasmaliah. 2004. Infeksi Pernapasan Akut (ISPA) dan Penanggulangannya. www.usu.ac.id, diakses tanggal 20 April 2020.

Retno, W. 2015. Survei Cepat Gambaran Kondisi Fisik RumahKaitannya dengan Kejadian Infeksi Saluran Pernapasan Akut (ISPA) pada Balita di Wilayah Kerja Puskesmas Kebumen 2 Kabupaten Kebumen. Jurnal Kesehatan Masyarakat. Vol.III/No.02/Oktober 2015, hal.33.

Riskedas. 2018. Hasil Utama Riskesdas 2018. Kementerian Kesehatan Badan Penelitian dan Pengembangan Kesehatan.

Rismawati, dkk. 2016. Hubungan Variasi Iklim Dengan Kejadian Pneumonia Pada Balita Di Kota Semarang Tahun 2011-2015 (Studi Kasus Di Wilayah Kerja Puskesmas Bandarharjo). Jurnal Kesehatan Masyarakat. Vol. 4, No. 5, Oktober 2016 : hal 160 - 169.

Saepudin, Ahmad. Evelin Margo. 2017. Hubungan Tingkat Pengetahuan Tentang Infeksi Saluran Pernafasan Akut dan Penggunaan Masker Pada Tukang Ojek. Fakultas Kedokteran Universitas Trisakti, Jakarta, Hal 1-16. 